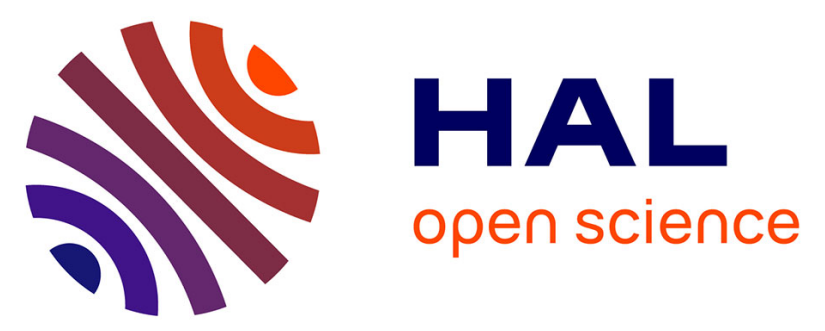

\title{
Mechanical, thermal and acoustical characterizations of an insulating bio-based composite made from sunflower stalks particles and chitosan
}

Narimane Mati-Baouche, Hélène de Baynast, André Lebert, Shengnan Sun, Carlos Javier Sacristan Lopez-Mingo, Philippe Leclaire, Philippe Michaud

\section{To cite this version:}

Narimane Mati-Baouche, Hélène de Baynast, André Lebert, Shengnan Sun, Carlos Javier Sacristan Lopez-Mingo, et al.. Mechanical, thermal and acoustical characterizations of an insulating bio-based composite made from sunflower stalks particles and chitosan. Industrial Crops and Products, 2014, 58, pp.244-250. 10.1016/j.indcrop.2014.04.022 . hal-01323684

\section{HAL Id: hal-01323684 \\ https://hal.science/hal-01323684}

Submitted on 31 May 2016

HAL is a multi-disciplinary open access archive for the deposit and dissemination of scientific research documents, whether they are published or not. The documents may come from teaching and research institutions in France or abroad, or from public or private research centers.
L'archive ouverte pluridisciplinaire HAL, est destinée au dépôt et à la diffusion de documents scientifiques de niveau recherche, publiés ou non, émanant des établissements d'enseignement et de recherche français ou étrangers, des laboratoires publics ou privés. 


\title{
Mechanical, thermal and acoustical characterizations of an insulating bio-based composite made from sunflower stalks particles and chitosan
}

\author{
Narimane Mati-Baouche a, Hélène De Baynast ${ }^{\mathrm{a}}$, André Lebert ${ }^{\mathrm{a}}$, Shengnan Sun ${ }^{\mathrm{a}}$, Carlos \\ Javier Sacristan Lopez-Mingo b, Philippe Leclaire ${ }^{b}$, Philippe Michaud ${ }^{\text {a, } *}$ \\ ${ }^{a}$ Clermont Université, Université Blaise Pascal, Institut Pascal UMR CNRS 6602, 24 avenue des Landais, BP-206, 63174, Aubière Cedex, France b Université de \\ Bourgogne, Laboratoire DRIVE, ISAT, 49 rue Mademoiselle Bourgeois, B.P. 3158027, Nevers Cedex, France
}

\begin{abstract}
This study has for objective the determination of thermal, mechanical and acoustical properties of insu-lating bio-based composite made with chitosan and sunflower's stalks particles. An experimental design was established to find the size grading of particles, the ratio chitosan/sunflower particles and the stress of compaction influencing the thermal and mechanical properties. Composites with a thermal conductiv-ity $(\kappa)$ of $0.056 \mathrm{Wm}^{-1} \mathrm{~K}^{-1}$, a maximum stress $\left(\sigma_{\max }\right)$ of $2 \mathrm{MPa}$ and an acoustic coefficient of absorption $(\alpha)$ of 0.2 were obtained with a ratio of chitosan of $4.3 \%(\mathrm{w} / \mathrm{w}$ ) and a size grading of particles higher to $3 \mathrm{~mm}$. These mechanical and thermal performances are competitive with those of other insulating bio-based materials available on the market.
\end{abstract}

\section{Introduction}

The implementation of agro-industrial residues in the development of composite materials for building trades is now a research of growing interest (Cole, 1999; Gustavsson and Sathre, 2006; Morel et al., 2001). One of the major challenges of this industry for the next decade is to improve the energy performance of existing buildings taking into account the increasing social emphasis on issues of the environment, waste disposal, and the depletion of non-renewable resources. The motivation includes cost, mechanical, thermal and acoustical performance enhancements, weight reduction, and environment concerns (Glé et al., 2012). In this context, bio-based insulator materials made from by-products of agriculture are an interesting alternative to those obtained from fossil carbon. Thermal insulation is known to play a critical role in saving energy by reducing the rate of heat transfer (Keynakli, 2012). A material is considered as a thermal insulator when its thermal conductivity $(\kappa)$ is lower than $0.1 \mathrm{~W} \mathrm{~m}^{-1} \mathrm{~K}^{-1}$, some of them reaching $0.035 \mathrm{~W} \mathrm{~m}^{-1} \mathrm{~K}^{-1}$ (Al-Homoud, 2005). They include fibrous and cellular inorganic materials, organic materials and metallic or metalized reflective membranes. Among them, those obtained from agricultural by-products have numerous advantages as they are eco-friendly and renewable. Moreover the high fiber content of some of them (wood, hemp, flax. ..) authorizes the reinforcement of composites (Liu et al., 2006). This property leads to the development of bio-based composites with natural fibers not only in the field of thermal insulators but also in other industrial areas such as paper or thermoplastic industries (Ashori, 2013; Ashori and Nourbakhsh, 2010; Ashori et al., 2014; Zahedi et al., 2013). Onésippe et al. (2010) have used sugar cane bagasse fibers in cement composites. The bio-sourced material obtained had higher thermal conductivity and mechanical strength compared to cement alone. Korjenic et al. (2011) carried out a research project to develop a new insulating material from jute, flax and hemp. Results showed that the correct combination of natural materials is comparable with convectional materials for mechanical properties. Furthermore, Elfordy et al. (2008), Nguyen et al. (2010), Nozahic and Amziane (2012) and Nozahic et al. (2012) characterized the hemp concrete, a new insulating material. Its thermal conductivity and its compressive strength were evaluated ranging between 0.1 and $0.4 \mathrm{~W} \mathrm{~m}^{-1} \mathrm{~K}^{-1}$ and from 0.2 to $0.8 \mathrm{MPa}$, respectively.

Sunflower is widely cultivated all over the world. In 2010 , the harvested area in Europe was $3.68 \times 10^{6}$ ha representing $16 \%$ of the total harvested area in the world (Sun et al., 2013). The crushed 
sunflower stems have no real application in agriculture and it has been estimated that each hectare of sunflower can produce 3-7 tons of dry biomass including stems (Marechal and Rigal, 1999). The stems are usually burnt, used as natural fertilizer, for animal feed or for fuel production (Chen and Lu, 2006; Sun et al., 2013). In this context, non-food uses of a part of this biomass would have a significant economic impact on this culture (Ashori and Nourbakhsh, 2010; Laufenberg et al., 2003). Several authors reported that building products/composites produced from various agro-waste materials, including sunflower stalks, have higher mechanical properties, lower thermal conductivity and density, are cheaper, durable, lightweight, available in abundance, much less abrasive and environmental friendly compared to conventional ones (Ashori et al., 2014; Díaz et al., 2011; Madurwar et al., 2013; Zahedi et al., 2013). Bark of sunflower stems exhibit favorable mechanical properties whereas its pith has good insulation ones (Sun et al., 2013). Hence, this by-product could find use in a total bio-sourced composite with thermal insulator properties using a natural organic binder contrary to classical strategies which employed cement (Elfordy et al., 2008; Nguyen et al., 2010; Nozahic and Amziane, 2012 and Nozahic et al., 2012) or epoxy resin (Binici et al., 2014). Chitosan is a natural polymer obtained industrially by deacetylation of chitin from crustacean shells (Dash et al., 2011; No et al., 2007). This polysaccharide, which is the most abundant polysaccharide after cellulose (Barbosa et al., 2005), is a heteropolymer of $\beta$-(1,4)-linked 2-acetamido-2-deoxy-D-glucopyranose and 2-amino-2-deoxy-D-glucopyranose units. It is the sole cationic polysaccharide described due to its positive charges $\left(\mathrm{NH}_{3}{ }^{+}\right)$at acidic $\mathrm{pH}(\mathrm{pH}<6.5)$ (Barbosa et al., 2005). Over the past few decades, chitosan has received attention as a functional non-toxic, antimicrobial, biocompatible and biodegradable biopolymer useable in the area of biomaterials and/or biosourced materials (Ashori et al., 2013; Dash et al., 2011; Kumar, 2000; Muzzarelli et al., 2012; Nair and Laurencin, 2007; No et al., 2007; Patel et al., 2013; Shalaby et al., 2004; Umemura et al., 2010). In the light of all its features chitosan was selected as a natural binder for the conception of a thermal insulating material using sunflower stalks particles as reinforcement.

\section{Material and methods}

\subsection{Raw materials}

\subsubsection{Shredded sunflower stalks}

The sunflower (reference LG5474) stalks used in this study were harvested in 2009 (Perrier, France). Grinding of sunflower stalks was performed using a cutting mill SM 300 (Retsch) with a sieve of $20 \mathrm{~mm}$ mesh. The speed cut applied was $1000 \mathrm{rpm}$. The particles obtained were sieved at room temperature $\left(20^{\circ} \mathrm{C}\right)$ using Controlab sieve-tronic to obtain different particles sizes between 1 and $6.3 \mathrm{~mm}$. Particles were stored at room temperature.

\subsubsection{Binder}

Chitosan from Shrimp Shell with a molecular weight of $98 \mathrm{kDa}$ and a deacetylation degree of $90 \%$ was supplied by France-Chitin (France) with the reference number 342 . The polysaccharide was solubilized at room temperature $\left(20^{\circ} \mathrm{C}\right)$ for $2 \mathrm{~h}$ under stirring at concentrations ranging between 2 and $9 \%(w / v)$ in acetic acid 1-2\% (v/v) (Sigma Aldrich, 98.9\%).

\subsection{Bio-based composite}

The process for obtaining bio-based composites from shredded stems of sunflower and chitosan is shown in Fig. 1. Chitosan solutions were mixed for $5 \mathrm{~min}$ with sunflower's stalk particles having different particle sizes (between 1.6 and $6.3 \mathrm{~mm}$ ). Ratios

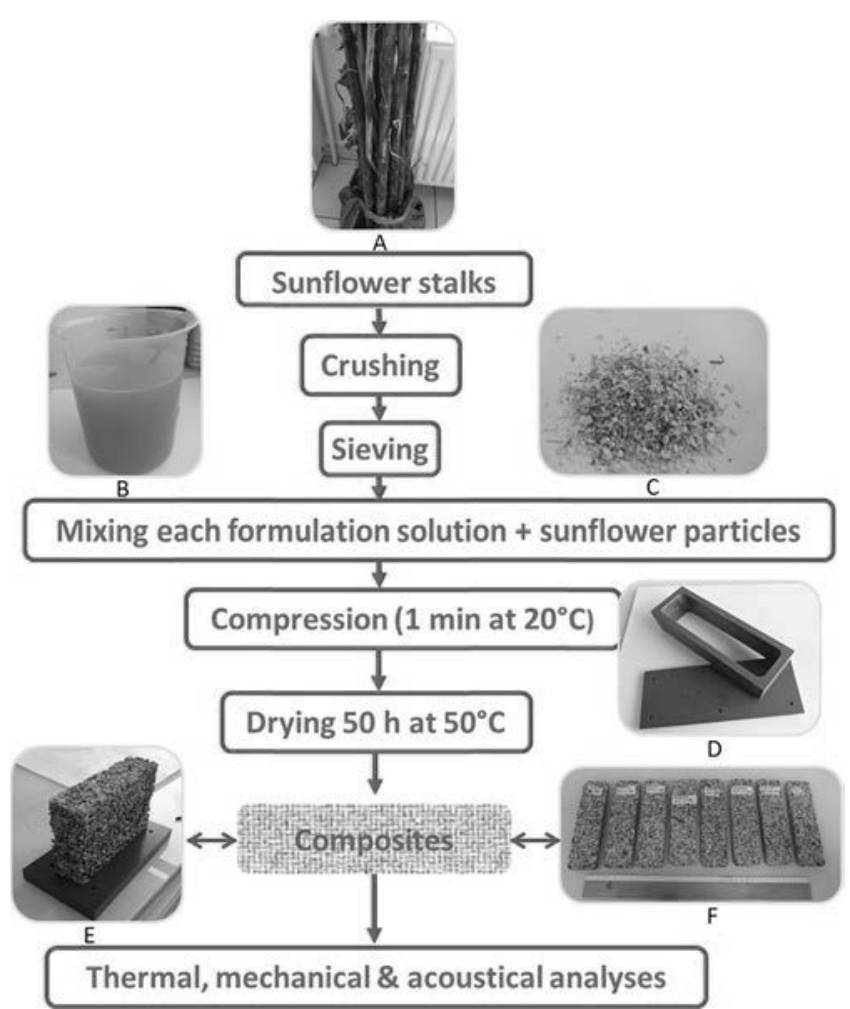

Fig. 1. Process of obtaining agro-composite from sunflower stalks and chitosan. (A) sunflower stalks (LG5474), (B) chitosan solutions at 2-9\% (w/v), (C) sunflower stalk particles (1-6 mm), (D) PVC mold, (E) composite sunflower/chitosan obtained for compressive analysis, (F) composites obtained for the tensile analysis.

chitosan/sunflower particles were between 0.04 and $0.15 \mathrm{~g} / \mathrm{g}$. Each type of mixture was prepared twice in two polyvinylchloride (PVC) molds: $180 \mathrm{~mm} \times 50 \mathrm{~mm} \times 40 \mathrm{~mm}$ for tensile tests and $180 \mathrm{~mm} \times 50 \mathrm{~mm} \times 120 \mathrm{~mm}$ for compressive measures. Each set was compacted during $1 \mathrm{~min}$ at $20^{\circ} \mathrm{C}$ under pressures between $1 \times 10^{-3}$ and $32 \times 10^{-3} \mathrm{MPa}$ using weights or compressive press machine (Zwick-Roell) equipped with a $\pm 20 \mathrm{kN}$ load cell for pressures between $156 \times 10^{-3}$ and $574 \times 10^{-3} \mathrm{MPa}$. After drying at $50^{\circ} \mathrm{C}$ for $50 \mathrm{~h}$ in an oven, the resulting composites were firstly thermally characterized (Fig. 1) and then cut with a band saw to obtain slender shapes of $180 \mathrm{~mm} \times 24 \mathrm{~mm} \times 12 \mathrm{~mm}$ for tensile mechanical characterization (Fig. 2). Specimens obtained for compressive tests were also cut to obtain slender shape (Fig. 2). Composites failed by buckling when their critical load was reached. As a consequence, the shape of specimens was defined at $80 \mathrm{~mm} \times 50 \mathrm{~mm} \times 50 \mathrm{~mm}$ using Euler equation (1) to avoid the phenomenon of buckling during compressive tests:

$P=\frac{\pi^{2} E I}{l^{2}}$

where " $P$ " is the allowable load $(\mathrm{N})$; " $E$ " the Young modulus (kPa); "I" is the moment of inertia $\left(\mathrm{mm}^{4}\right)$ and " $l$ " is the length of the sample $(\mathrm{mm})$.

For the acoustical analysis, five composites made with sunflower particles of $5 \mathrm{~mm}$, a ratio chitosan/sunflower stalks particles of $6 \%$ $(\mathrm{w} / \mathrm{w})$ and a compaction pressure of $32 \mathrm{kPa}$, were cut into circles with a diameter of $29 \mathrm{~mm}$ and a thickness of $13 \mathrm{~mm}$.

Composites with labelled chitosan were built using $2 \mathrm{~g}$ of RITClabelled chitosan dissolved in a solution of $50 \mathrm{ml}$ of $1 \%(\mathrm{v} / \mathrm{v})$ acetic acid. This solution was mixed with $30 \mathrm{~g}$ of sunflower stalk particles. After that, the set was compacted with a stress pressure of $32 \mathrm{kPa}$ in PVC mold of $180 \mathrm{~mm} \times 50 \mathrm{~mm} \times 20 \mathrm{~mm}$ before being dried in an oven for $50 \mathrm{~h}$ at $50^{\circ} \mathrm{C}$. 


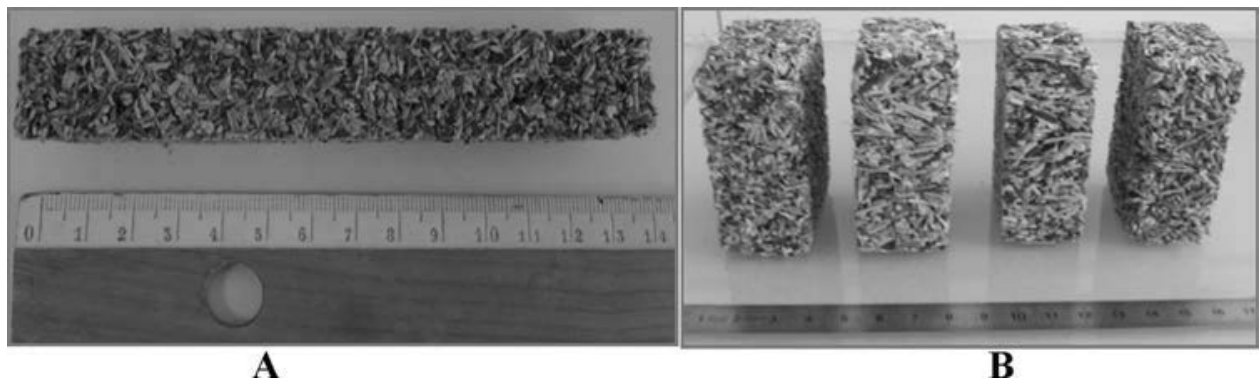

Fig. 2. Composites chitosan/sunflower stalk aggregates before tensile (A) and compressive (B) analysis.

\subsection{Biochemical characterization}

An estimation of the parietal constituents of sunflower stalks on both pith and bark was performed using the Henneberg and Stohmann (1860) protocol to quantify cellulose and the procedure of Jarrige (1961) to evaluate the amount of lignin. All assays were done in triplicate.

\subsection{Thermal characterization}

Thermal characterization of several specimens of sunflower stem particles/chitosan composites was carried out by measuring thermal conductivities $(\kappa)\left(\mathrm{W} \mathrm{m}^{-1} \mathrm{~K}^{-1}\right)$ in different points on the samples by the hot wire method (NeoTIM FP2C) at $20^{\circ} \mathrm{C}$. Thermal conductivity is evaluated by tracking the thermal pulse propagation induced in the sample by a heating source consisting of a nickel alloy wire. The temperature is measured on the wire by means of two T type (Copper-Constantan) thermocouples (Franco, 2007). The nickel wire is used to slightly heat up the samples with the passage of an electrical current and to monitor the temperature increase by recording the variation of the voltage across the wire. The thermal conductivity is determined from the time-dependent temperature increase. A mean thermal conductivity was determined from five measurements on each sample for a temperature of $21^{\circ} \mathrm{C}$ and a relative humidity close to $40 \%$.

\subsection{Mechanical characterization}

Mechanical characterization was performed using a tensile testing machine (Instron 5543) equipped with a load cell of $5 \mathrm{kN}$. The cross-head speed was equal to $5 \mathrm{~mm} \mathrm{~min}^{-1}$ and the specimen clamping length was $140 \mathrm{~mm}$. Compressive tests were carried out with a Zwick-Roell testing machine equipped with a $\pm 20 \mathrm{kN}$ load cell. The tests were displacement-controlled with a cross-head speed equal to $1.2 \mathrm{~mm} \mathrm{~min}^{-1}$. The tested specimens were placed between two steel plates to have homogeneous displacement and pressure and the load was applied on the superior surface. The results of the mechanical tests were analyzed through stress-strain curves. These curves present typically two areas. One corresponds to the deformation (elongation), which is proportional to the stress and corresponds to an elastic reversible strain. The other one, corresponding to a plastic area, represents the part when the strain is non-linear and irreversible. The maximum stress $\left(\sigma_{\max }\right)(\mathrm{MPa})$ was measured in both tensile and compressive modes. The strain at break $\varepsilon_{b}(\%)$ (percentage of elongation at break) was evaluated only in the tensile mode.

\subsection{Acoustical characterization}

The measurements were carried out in an impedance tube and based on two-microphones transfer-function method. A sound wave is generated at one end of the tube by a loudspeaker. The wave can be considered as a plane wave if its frequency is below a cut off determined by the tube diameter. After a reflection at the surface of the material at the other end of the tube, the sound field created in the tube is a standing sound field and depends on the reflection coefficient at the surface of the material. The two microphones measure the sound field at two different positions. The loudspeaker can be fed with a white noise signal and the incident and reflected sound pressure recorded by the microphones are then processed to deduce the absorption coefficient of the sample in a frequency band. For a $29 \mathrm{~mm}$ diameter tube, the useful frequency band is between $500 \mathrm{~Hz}$ and $6400 \mathrm{~Hz}$. Composite samples were placed at the end of the impedance tube and backed by a rigid surface.

\subsection{Synthesis of rhodamine-labelled chitosan}

The synthesis of rhodamine-labelled chitosan was done as described by Patel et al. (2013). The final concentration of rhodamine isothiocyanate (RITC) in the reaction medium was controlled to give a ratio of labelled $D$-glucosamine residue ratio equal to 1:50. Two grams of dried chitosan powder were dissolved in $200 \mathrm{ml}$ of acetic acid at $0.1 \mathrm{moll}^{-1}$. Subsequently, $200 \mathrm{ml}$ of dehydrated methanol were slowly added in this solution under continuous stirring. Rhodamine-isothiocynate (RITC, Sigma Aldrich) dissolved in methanol at $1.0 \mathrm{mg} \mathrm{ml}^{-1}$ was then slowly added to the solution of chitosan. The reaction was realized during $1 \mathrm{~h}$ in dark at room temperature $\left(20^{\circ} \mathrm{C}\right)$. RITC-labelled chitosan was then precipitated in a solution of sodium hydroxide at $0.1 \mathrm{moll}^{-1}$ The precipitate was washed with deionized distilled water until complete absence of free RITC in the washing medium. The labelled chitosan was then freeze-dried. The yield was $85 \%$ as described by Qaqish and Amiji (1999).

\subsection{Microscopy}

Composites of rhodamine-labelled chitosan/sunflower stalks particles were observed at magnification $6.3 \times$ under light microscopy in the aim to characterize the bonding area by investigating the adhesive penetration of chitosan into sunflower cells.

Observations in scanning electron microscopy (SEM, Jeol 820) were conducted on sections of sunflower stalks on both bark and pith. The samples were metalized with a physical vapor deposition (PVD) thin layer of gold and were observed with secondary electrons detector. The magnification range covered is between 200 and 15,000 . The working distance and acceleration potential were equal to $15 \mathrm{~mm}$ and $10 \mathrm{kV}$, respectively.

\subsection{Experimental design and statistical analysis}

Preliminary testing of the design of composite chitosan/shredded sunflower stalks showed the feasibility of this mixture. To find the best values of the three process parameters affecting the thermal and mechanical properties, namely, the 
Table 1

Area of variations of the operating parameters.

\begin{tabular}{clcl}
\hline Level & Particle size $(\mathrm{mm})$ & Ratio $(\%)$ & $\begin{array}{l}\text { Compaction pressure } \\
\left(10^{-3} \mathrm{MPa}\right)\end{array}$ \\
\hline+1.68 & 6.30 & 15.3 & 574 \\
+1 & 5.00 & 13.3 & 373 \\
0 & 3.12 & 10.0 & 156 \\
-1 & 2.00 & 6.6 & 32 \\
-1.68 & 1.60 & 4.3 & 1 \\
\hline
\end{tabular}

particle size, the ratio chitosan/shredded sunflower stalks and compaction stress, and to minimize the number of tests, a composite central design was chosen. This plan used consists of 24 trials $(N)$ corresponding to $N=2^{n}+2 . N=14$ points plus 10 repetitions of the central point. Each factor is studied at five levels as shown in Table 1 . The associated model is a quadratic polynomial with the linear and quadratic effects and all the interaction effects between the different operating variables effects. Three variables were modeled with this experimental design: thermal conductivity $(k)$ $\left(\mathrm{W} \mathrm{m}^{-1} \mathrm{~K}^{-1}\right)$, Young's modulus $\mathrm{E}^{\prime}(\mathrm{MPa})$ and the maximum stress $\sigma_{\max }(\mathrm{MPa})$. The results were analyzed by the statistical software R 2.15.2 (R Core Team, 2012). The optimal thermal insulation and mechanical strength were achieved by using a quadratic model with interactions.

\section{Results and discussion}

The elaboration of a new composite from agricultural byproducts has a great interest for the society. This study focuses on the development and the characterization of a thermal insulating agro-composite made from sunflower stalks particles glued with chitosan.

Table 2 shows the humidity, parietal content and global dimensions of the used sunflower stalk particles. The cellulose amounts were estimated at $48 \%$ for bark and $31.5 \%$ for pith, whereas the lignin contents were $14 \%$ and $2.5 \%$ for bark and pith, respectively. These results are in good agreement with those obtained by Marechal and Rigal (1999) using chemical method leading to the conclusion that bark is responsible of the rigidity of sunflower stem.

\subsection{Mechanical and thermal properties of the bio-based composites}

Mechanical properties are of primary importance to quantify the performances of materials expected to undergo various types of stresses during their implementation. Young's modulus, also called the elastic modulus, corresponds to the stiffness of the specimen. More Young's modulus increases more rigid is the material. $\sigma_{\max }$ is the maximum stress reached during tensile or compressive tests that the sample can sustain before being broken. These two parameters characterize the mechanical strength of the material. The thermal performances are evaluated when the conception of insulating material is aimed. More the thermal conductivity of a material is low (less than $0.1 \mathrm{~W} \mathrm{~m}^{-1} \mathrm{~K}^{-1}$ ) more the thermal insulation is significant. An experimental design centered on 24 trials was chosen to study the influence of the process parameters (particle size, compaction pressure and ratio binder/reinforcement) about values of Young's modulus $\left(\mathrm{E}^{\prime}\right)$, maximum stress $\left(\sigma_{\max }\right)$ and thermal conductivity $(\kappa)$ of the composites chitosan/shredded sunflower stalks. All the composites manufactured in this study had density between 150 and $200 \mathrm{~kg} \mathrm{~m}^{3}$. Table 3 summarizes results from this experimental design in terms of mechanical strength and insulating properties.

Knowing that a material is qualified as insulating when its thermal conductivity is less than $0.1 \mathrm{~W} \mathrm{~m}^{-1} \mathrm{~K}^{-1}$ (Abdou and Boudaiwi, 2013) the composites obtained in this study can be considered as insulators because of their thermal conductivities between 0.056 and $0.058 \mathrm{~W} \mathrm{~m}^{-1} \mathrm{~K}^{-1}$ depending on the manufacturing conditions. These thermal performances are better than those of sunflower fiberboards $\left(\kappa=0.088 \mathrm{~W} \mathrm{~m}^{-1} \mathrm{~K}^{-1}\right)$ manufactured from sunflower whole plant using hydraulic press and other ecofriendly insulating materials available on the market, namely hemp concrete ( $\kappa$ between 0.17 and $0.48 \mathrm{~W} \mathrm{~m}^{-1} \mathrm{~K}^{-1}$ ), coconut husk insulation boards $\left(\kappa=0.081 \mathrm{~W} \mathrm{~m}^{-1} \mathrm{~K}^{-1}\right)$ and date palm fibers insulation boards $\left(\kappa=0.15 \mathrm{~W} \mathrm{~m}^{-1} \mathrm{~K}^{-1}\right.$ ) (Chikhi et al., 2013; Elfordy et al., 2008 and Evon et al., 2014). They are also slightly higher than the thermal conductivities of the current "non-bio-based" insulating products such as rock wool $\left(\kappa=0.04 \mathrm{~W} \mathrm{~m}^{-1} \mathrm{~K}^{-1}\right)$, mineral wool $\left(\kappa=0.036 \mathrm{~W} \mathrm{~m}^{-1} \mathrm{~K}^{-1}\right)$ and fiber glass $\left(\kappa=0.035 \mathrm{~W} \mathrm{~m}^{-1} \mathrm{~K}^{-1}\right)$ (Abdou and Boudaiwi, 2013). However, these insulators have very low mechanical resistance and require very specific processes for their maintenance in the building. Mechanical properties of the bio-based composites chitosan/sunflower stalks particles used in tensile mode attained up to $2.6 \mathrm{MPa}$ for $\sigma_{\max }, 250 \mathrm{MPa}$ for $\mathrm{E}^{\prime}$ and $2 \%$ for the $\varepsilon_{b}$ whereas those used in compressive mode reached $2 \mathrm{MPa}$ and for $\sigma_{\max }, 25 \mathrm{MPa}$ for $\mathrm{E}^{\prime}$. These results revealed that this kind of bio-based composites present higher mechanical properties than the hemp concrete knowing as "the green insulator concrete". Indeed, the compressive strength (equivalent to the maximal stress in compressive mode) of this material is described lower than $2 \mathrm{MPa}$ (Nozahic and Amziane, 2012). Furthermore, Elfordy et al. (2008)

Table 2

Characteristics of the studied sunflower's stalks.

\begin{tabular}{|c|c|c|c|c|c|c|}
\hline & Humidity (\%) & Cellulose (\%) & Lignine (\%) & Mean length (mm) & Mean width (mm) & Mean thickness (mm) \\
\hline Pith & 13 & 31.5 & 2.5 & $1-6.3$ & $1-6.3$ & $0.5-2$ \\
\hline Bark & 13 & 45 & 14 & $1-6.3$ & $1-6.3$ & $0.5-2$ \\
\hline
\end{tabular}

Table 3

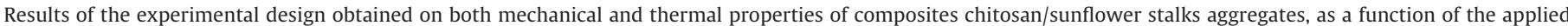
compaction pressure, the size of sunflower particles and the ratio chitosan/sunflower.

\begin{tabular}{|c|c|c|c|c|}
\hline & Optimal properties & Compaction $\left(10^{-3} \mathrm{MPa}\right)$ & Size of particles (mm) & Ratio (w/w) chitosan/sunflower (\%) \\
\hline \multirow{3}{*}{ Tensile mode } & $\mathrm{E}^{\prime}=250 \mathrm{MPa}$ & 574 & 3.1 & 15.38 \\
\hline & $\sigma_{\max }=2 \mathrm{MPa}$ & 574 & 6.3 & $p^{a}$ \\
\hline & $\kappa=0.056 \mathrm{~W} \mathrm{~m}^{-1} \mathrm{~K}^{-1}$ & 574 & 6.3 & 4.38 \\
\hline \multirow[t]{3}{*}{ Compressive mode } & $\mathrm{E}^{\prime}=25 \mathrm{MPa}$ & 574 & 6.3 & 15.38 \\
\hline & $\sigma_{\max }=2.6 \mathrm{MPa}$ & 574 & 6.3 & 15.38 \\
\hline & $\kappa=0.058 \mathrm{~W} \mathrm{~m}^{-1} \mathrm{~K}^{-1}$ & 1 & 6.3 & 4.38 \\
\hline
\end{tabular}

\footnotetext{
a No significant effect was observed.
} 


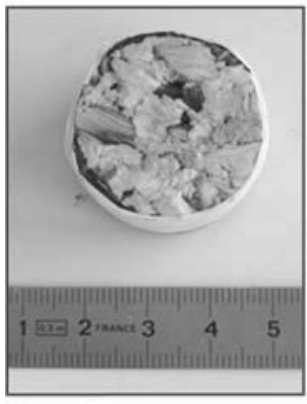

A

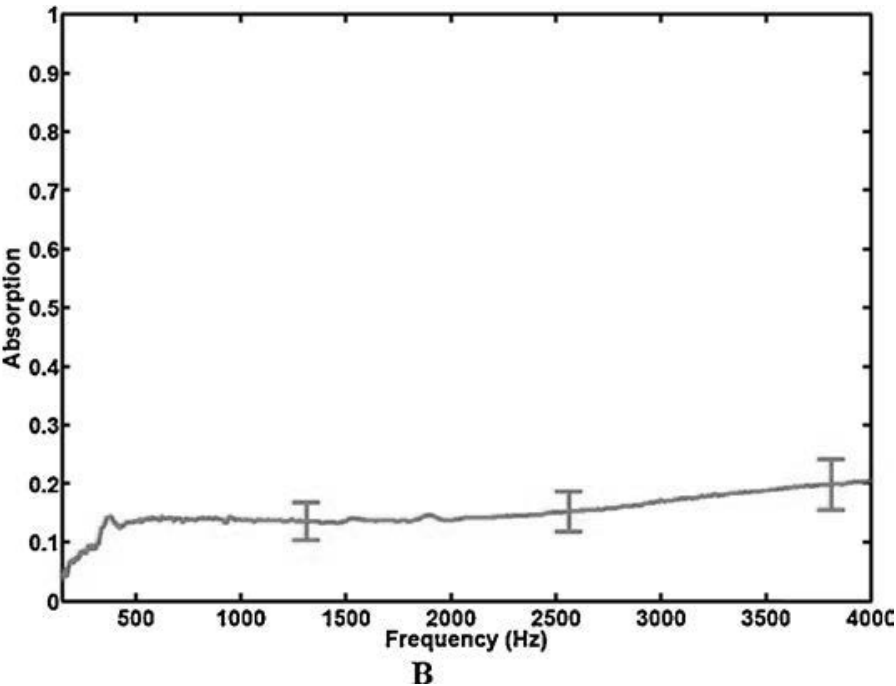

B

Fig. 3. Sound absorption (B) of composite (A) made from sunflower stalk's aggregates and chitosan with thickness of $13 \mathrm{~mm}$.

have measured both Young's modulus and compressive strength of hemp concrete blocks with various densities (between 291 and $481 \mathrm{~kg} \mathrm{~m}^{-3}$ ). They have obtained Young's modulus ranging from 7 to $35 \mathrm{MPa}$ and compressive strengths ranging between 0.18 and $0.8 \mathrm{MPa}$.

Analyses of results from Table 3 allow the following trends for each studied parameter:

The size of sunflower stalks particles greater than $3.1 \mathrm{~mm}$ permits the production of composites with optimum mechanical and thermal performances $\left(E^{\prime}=250 \mathrm{MPa}, \sigma_{\max }=2.6 \mathrm{MPa}\right.$ $\left.\kappa=0.056 \mathrm{~W} \mathrm{~m}^{-1} \mathrm{~K}^{-1}\right)$.

Compaction pressures used to make composites (between $1 \times 10^{-3}$ and $574 \times 10^{-3} \mathrm{MPa}$ ) influence significantly their thermal and mechanical properties. Compaction is the ability of the sample to acquire cohesion and hence resistance for maximum sustained pressure. Results showed that the greater thermal conductivities were attained with compaction pressure of $10^{-3} \mathrm{MPa}$ for the samples made for compressive measurements $\left(0.058 \mathrm{~W} \mathrm{~m}^{-1} \mathrm{~K}^{-1}\right)$ and $574 \times 10^{-3} \mathrm{MPa}$ for the samples made for tensile measurements $\left(0.056 \mathrm{~W} \mathrm{~m}^{-1} \mathrm{~K}^{-1}\right)$. This result is surprising because the thermal conductivity $(\kappa)$ of the most compacted material $\left(574 \times 10^{-3} \mathrm{MPa}\right)$, thus containing less air, is lower $\left(0.056 \mathrm{~W} \mathrm{~m}^{-1} \mathrm{~K}^{-1}\right)$. This phenomenon can be explained by the creation of radiative heat transfer on the highly compacted material as described by Pennec et al. (2013). Higher mechanical performances ( $\mathrm{E}^{\prime}$ and $\sigma_{\max }$ ) appeared with significant compaction pressures for the two kinds of composites (tensile and compressive modes). From the mechanical point of view, this behavior can be linked to the work of Nguyen et al. (2010) who have shown that compaction leads gains strength for hemp concrete composites.

The increase of chitosan/sunflower ratio is logically correlated with the increase of the mechanical strength. This result is not surprising because the chitosan solid state endowed a tensile strength of $70 \mathrm{MPa}$ and Young modulus between 2 and $4 \mathrm{GPa}$, which reflects a rigid behavior (Mati-Baouche et al., 2014). The Young modulus of the bio-based composite was optimal (250 MPa) when the ratio $(\mathrm{w} / \mathrm{w})$ of chitosan/sunflower reached $15.3 \%$, which means that the amount of binder has a direct impact on the strength of the final material. Logically, this increase in mechanical performances is correlated with a loss of thermal one $\left(\kappa=0.066 \mathrm{~W} \mathrm{~m}^{-1} \mathrm{~K}^{-1}\right)$ because of appearance of thermal bridges in the composite and reduction of the pore spaces of shredded sunflower stalks (Pennec et al., 2013).

\subsection{Acoustical properties of the composite chitosan/sunflower stalks particles}

Nowadays, building materials are expected to perform several functions and to be sustainable. For example, building materials are supposed to satisfy structural, thermal and acoustical demands (Glé et al., 2011). Hence, acoustical characterization was performed on the composites presenting the best mechanical and thermal compromise. Samples made from $5 \mathrm{~mm}$ sunflower stalk's particles, with a $6.6 \%$ ratio chitosan/sunflower $(\mathrm{w} / \mathrm{w})$ and compacted with a pressure of $32 \mathrm{kPa}$ during the manufacturing, were analyzed with the $29 \mathrm{~mm}$ diameter impedance tube. Fig. 3 represents the sound absorption coefficient $(\alpha)$ of the composite, with thickness of $13 \mathrm{~mm}$, in the frequency ranging from 0 to $4000 \mathrm{~Hz}$. Note that this range of frequencies is used in the construction field to evaluate the acoustic insulating properties of materials. When toward 1, all the energy of the incident wave is absorbed and when $\alpha=0$, the sound is not dampened at all (El Hajj et al., 2011). The absorption coefficient of the bio-based composite tested is lower than $0.5(\alpha \approx 0.2$ at frequency $2500-4000 \mathrm{~Hz}$ ). Knowing that a composite sugarcane waste fibers/polyester endowed a coefficient of absorption $\alpha \geq 0.5$ (Putra et al., 2013) above $3500 \mathrm{~Hz}$ and that agro-sourced materials from auto link flax-tows had a $\alpha \equiv 0.8$ at $3000 \mathrm{~Hz}$ (El Hajj et al., 2011), the acoustical performance of the bio-based composite developed here can be considered as low. If the composite is too tight, the acoustic wave cannot penetrate in it as described for cellular concrete (Cerezo, 2005). The acoustic absorption in a porous material

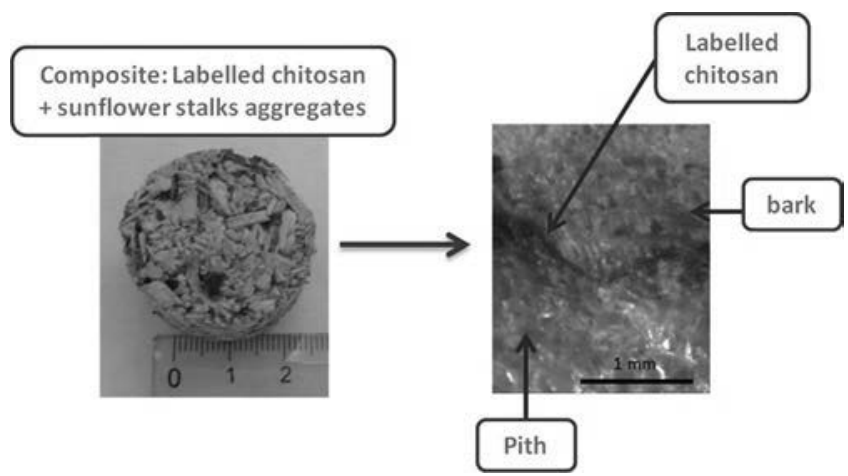

Fig. 4. Light microscopic observation at a magnification $6.3 \times$ of the composite chitosan/sunflower stalks aggregates after labelling chitosan. 


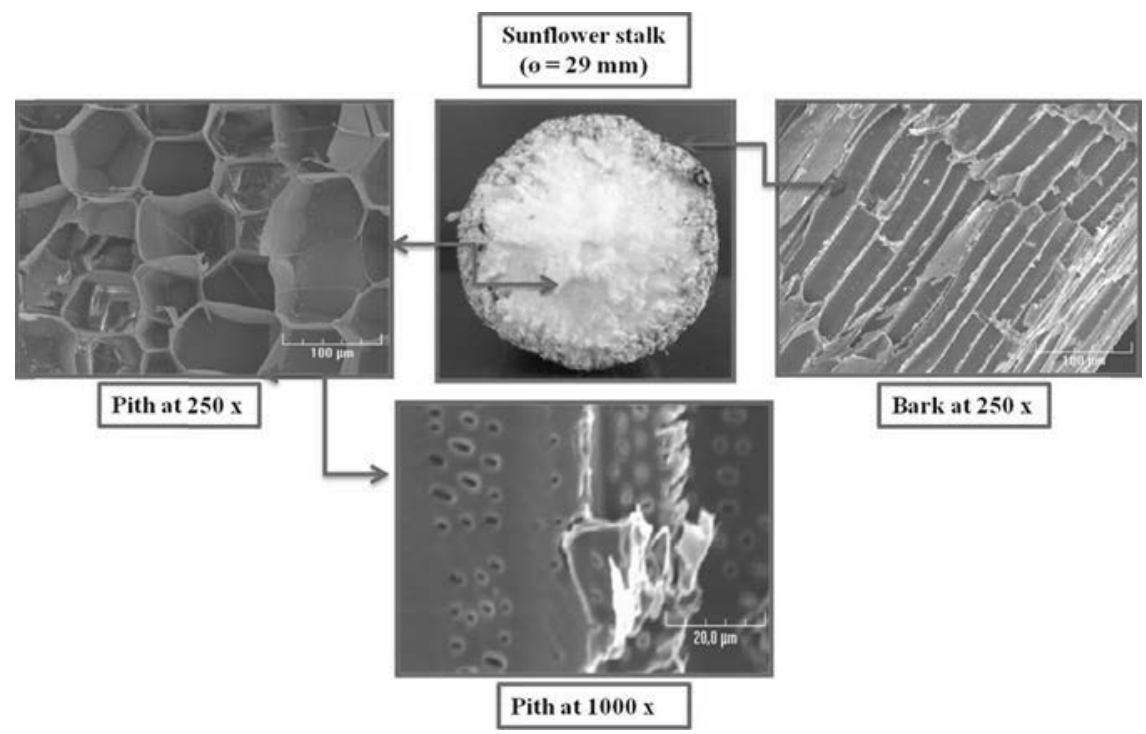

Fig. 5. SEM observations of pith and bark of sunflower stalk cells.

strongly depends upon several parameters among which the flow resistivity. For high values of flow resistivity, the sound attenuation can be low and explain the results of Fig. 3. Higher values of absorption can be expected for more porous materials (Glé et al., 2011).

\subsection{Penetration of chitosan in sunflower stalks's cells}

The chitosan being not visible inside and around the sunflower particles and cells, RITC-labelled chitosan was synthesized as described in methods using the reactivity of isothiocyanate functional groups of RITC moiety with the primary amine group of D-glucosamine residues of chitosan. Fig. 4 provides evidence that rhodamine-labelled chitosan did not penetrate into the sunflower cell walls and therefore did not reach the cell lumens although a double porosity ( $50-200 \mu \mathrm{m}$ and $2-10 \mu \mathrm{m}$ ) was observed by SEM (Fig. 5). Note that pith and bark have a honeycomb structure as described by El Hajj et al. (2012) on flax-shaves. So, rhodaminelabelled chitosan only interacted with the outer surface of the plant cell as reported by Patel et al. (2013) on wood cells and does not take the place of air preserving thermal insulating properties of the agrocomposite. This non-penetration of chitosan inside sunflower cells was explained by its viscosity and critical overlap concentration previously reported by Mati-Baouche et al. (2014).

\section{Conclusion}

The critical discussion about the preservation of natural resources and recycling has led to a renewed interest in natural materials with the focus on renewable raw materials. The objective of this work was to develop a method of manufacturing eco-insulating materials $100 \%$ natural based on sunflower stalks particles glued with binder based on chitosan solution, highlighting the factors that affect the mechanical and thermal properties of the bio-based composite. It was clearly shown that the thermal and mechanical performances of the composites were proportionately improved with the increasing of compaction pressure. The mechanical performances of the composites elaborated in this study are sufficient to ensure safe handling, transport and assembly. Composites with a thermal conductivity of $0.06 \mathrm{~W} \mathrm{~m}^{-1} \mathrm{~K}^{-1}$ and a maximum stress at break of about 2 MPa were obtained with a ratio chitosan/sunflower of $4.3 \%$, a particle size of shredded sunflower stalks of $6.3 \mathrm{~mm}$ and a density of $150 \mathrm{~kg} \mathrm{~m}^{-3}$. No penetration of the chitosan binder inside the sunflower cells was observed meaning the preservation of the natural properties of sunflower stalks's particles. In addition, acoustical study was performed on the best composite leading to the conclusion that its performance is low in the area of acoustic insulating.

\section{Acknowledgement}

This work was supported by the French National Research Agency (ANR-DEMETHER-10-ECOT-004 grant) and the French clusters: Céréales Vallée and Viaméca.

\section{References}

Abdou, A., Boudaiwi, I., 2013. The variation of thermal conductivity of fibrous insulation materials under different levels of moisture content. Constr. Build. Mater 43, 533-544.

Al-Homoud, M.S., 2005. Performance characteristics and practical applications of common building thermal insulation materials. Build. Environ. 40, 353-366.

Ashori, A., 2013. Effects of nanoparticles on the mechanical properties of rice straw/polypropylene composites. Compos. Mater. 47, 149-154.

Ashori, A., Nourbakhsh, A., 2010. Bio-based composites from waste agricultural residues. Waste Manage. 30, 680-684

Ashori, A., Cordeiro, N., Faria, M., Hamzeh, Y., 2013. Effect of chitosan and cationic starch on the surface chemistry properties of bagasse paper. Int. J. Biol. Macromol. 58, 343-348.

Ashori, A., Nourbakhsh, A., Kazemi Tabrizi, A., 2014. Thermoplastic hybrid composites using bagasse corn stalk and E-glass fibers; fabrication and characterization. Polym. Plast. Technol. 53, 1-8.

Barbosa, M.A., Granja, P.L., Barrias, C.C., Amaral, I.F., 2005. Polysaccharides as scaffolds for bone regeneration. ITBM-RBM 26, 212-217.

Binici, H., Eken, M., Dolaz, M., Aksogan, O., Kara, M., 2014. An environmentally friendly thermal insulation material from sunflower stalk textile waste and stubble fibres. Constr. Build. Mater. 51, 24-33.

Cerezo, V., June 16, 2005. Propriétés mécaniques, thermiques et acoustiques d'un matériau à base de particules végétales: approche expérimentale et modélisation théorique. Thesis of Institut national des sciences appliquées de Lyon, Lyon.

Chen, J.H., Lu, X.F., 2006. Progress in bio-fuel combustion in circulating fluidized bed boiler. Trans. Chin. Soc. Agric. Eng. 22, 267-270.

Chikhi, M., Boudjemaa, A., Boudenne, A., Gherabli, A., 2013. Experimental investigation of new biocomposite with low cost for thermal insulation. Energ. Build. 66, $267-273$.

Cole, R.J., 1999. Energy and greenhouse gas emissions associated with the construction of alternative structural systems. Build. Environ. 34, 335-348.

Dash, M., Chiellini, F., Ottenbrite, R.M., Chiellini, E., 2011. Chitosan - a versatile semisynthetic polymer in biomedical applications. Progr. Polym. Sci. 36, 981-1014.

Díaz, M.J., Cara, C., Ruiz, E., Pérez-Bonilla, M., Castro, E., 2011. Hydrothermal pretreatment and enzymatic hydrolysis of sunflower stalks. Fuel 90, 3225-3229. 
Elfordy, S., Lucas, F., Trancret, F., Scudeller, Y., Goudet, L., 2008. Mechanical and thermal properties of lime and hemp concrete (hempcrete) manufactured by a projection process. Constr. Build. Mater. 22, 2116-2123.

El Hajj, N., Mboumba-Mamboundou, B., Dheilly, R.M., Aboura, Z., Benzeggagh, M. Queneudec, M., 2011. Development of thermal insulating and sound absorbing agro-sourced materials from auto linked flax-tows. Ind. Crops Prod. 34, 921-928.

El Hajj, N., Dheilly, R.M., Goullieux, A., Aboura, Z., Benzeggagh, M.L., Quéneudec, M., 2012. Innovant agromaterials formulated with flax shaves and proteinic binder: process and characterization. Composites Part B 43, 381-390.

Evon, P., Vandenbossche, V., Pontalier, P.Y., Rigal, L., 2014. New thermal insulation fiberboards from cake generated during biorefinery of sunflower whole plant in a twin-screw extruder. Ind. Crops Prod. 52, 354-362.

Franco, A., 2007. An apparatus for routine measurement of thermal conductivity of materials for building application based on a transient hot-wire method. Appl. Therm. Eng. 27, 2495-2504.

Glé, P., Gourdon, E., Arnaud, L., 2011. Acoustical properties of materials made of vegetable particles with several scales of porosity. Appl. Acoust. 72, 249-259.

Glé, P., Gourdon, E., Arnaud, L., 2012. Modelling of the acoustical properties of hemp particles. Constr. Build. Mater. 37, 801-811.

Gustavsson, L., Sathre, R., 2006. Variability in energy and carbon dioxide balances of wood and concrete building materials. Build. Environ. 41, 940-951.

Henneberg, W., Stohmann, F., 1860. Beiträge zur Begründung einer rationellen Fütterung der Wiederkäuer, Heft 1. Schwetschke und Sohn, Braunschweig, Deutschland.

Jarrige, R., 1961. Analyse des constituants des plantes fourragères. I. Fractionnement des constituants de la membrane par les hydrolyses acides. Ann. Biol. Anim. Biochim. Biophys. 1, 163-212.

Keynakli, O., 2012. A review of the economical and optimum thermal insulation thickness for building applications. Renew. Sust. Energ. Rev. 16, 415-425.

Korjenic, A., Petranek, V., Jiri, Z., Jitka, H., 2011. Development and performance evaluation of natural thermal insulation materials composed of renewable resources. Energy Build. 43, 2518-2523.

Kumar, R.M.N.V., 2000. A review of chitin and chitosan applications. React. Funct. Polym. 46, 1-27.

Laufenberg, G., Kunz, B., Nystroem, M., 2003. Transformation of vegetable waste into value added products: (A) the upgrading concept; (B) practical implementations. Review Paper. Bioresour. Technol. 87, 167-198.

Liu, Z., Erham, S.Z., Akin, D.E., Barton, F.E., 2006. Green composites from renewable ressources: preparation of epoxidized soybean oil and flax fiber composites. J. Agric. Food Chem. 54, 2134-2137.

Madurwar, M.V., Ralegaonkar, R.V., Mandavgane, S.A., 2013. Application of agrowaste for sustainable construction materials: a review. Constr. Build. Mater. 38, 872-878.

Marechal, V., Rigal, L., 1999. Characterization of by-products of sunflower culture commercial applications for stalks and heads. Ind. Crops Prod. 10, 185-200.

Mati-Baouche, N., De Baynast, H., Vial, C., Audonnet, F., Sun, S., Petit, E., Pennec, F., Prevot, V., Michaud, P., 2014. Physico-Chemical, Thermal and Mechanical Approaches for the Characterizations of Solubilized and Solid State Chitosans (under review).
Morel, J.C., Mesbah, A., Oggero, M., Walker, P., 2001. Building houses with local materials: means to drastically reduce the environmental impact of construction. Build. Environ. 36, 1119-1126.

Muzzarelli, R.A.A., Greco, F., Busilacchi, A., Sollazzo, V., Gigante, A., 2012. Chitosan, hyaluronan and chondroitin sulfate in tissue engineering for cartilage regeneration: a review. Carbohydr. Polym. 89, 723-739.

Nair, L.S., Laurencin, C.T., 2007. Biodegradable polymers as biomaterials. Prog. Polym. Sci. 32, 762-798.

Nguyen, T.T., Picandet, V., Carré, P., Lecompte, T., Amziane, S., Baley, C., 2010. Effect of compactness on mechanical and thermal properties of hemp concrete. Eur. J. Environ. Civil Eng. 14, 545-560.

No, H.K., Meyers, S.P., Prinyawiwatkul, W., Xu, Z., 2007. Applications of chitosan for improvement of quality and shelf life of foods: a review. J. Food Sci. 72, 87-100

Nozahic, V., Amziane, S., 2012. Influence of sunflower aggregates surface treatments on physical properties and adhesion with a mineral binder. Composites Part A 43, 1837-1849.

Nozahic, V., Amziane, S., Torrent, G., Saïdi, K., De Baynast, H., 2012. Design of green concrete made of plant-derived aggregates and a pumice-lime binder. Cement Concr. Comp. 34, 231-241.

Onésippe, C., Passe-Coutrin, N., Toro, F., Delvasto, S., Bilba, K., Arsène, M.A., 2010 Sugar cane bagasse fibres reinforced cement composites: thermal considerations. Composites Part A 41, 549-556.

Patel, A.K., Michaud, P., Petit, E., De Baynast, H., Grédiac, M., Mathias, J.D., 2013. Development of chitosan-based adhesive. Application to wood bonding. J. Appl. Polym. Sci. 127, 5014-5021.

Pennec, F., Alzina, A., Tessier-Doyen, N., Naït-Ali, B., Mati-Baouche, N., De Baynast, H., Smith, D.S., 2013. A combined finite-discrete element method for calculating the effective thermal conductivity of bio-aggregates based materials. Int. J. Heat Mass Tran. 60, 274-283.

Putra, A., Absullah, Y., Efendy, H., Farid, W.M., Ayob, M.R., Py, M.S., 2013. Utilizing sugarcane wasted fibers as a sustainable acoustic absorber. Procedia Eng. 53, 632-638.

Qaqish, R.B., Amiji, M.M., 1999. Synthesis of a fluorescent chitosan derivative and its application for the study of chitosan-mucin interactions. Carbohydr. Polym. 3 99-107.

R Core Team, 2012. R: A Language and Environment for Statistical Computing. R Foundation for Statistical Computing, Vienna, Austria, ISBN 3-900051-07-0 http://www.R-project.org/

Shalaby, W.S., Dubose, J.A., Shalaby, M., 2004. Chitosan-based systems. In: Shalaby, S.W., Burg, K.J.L. (Eds.), Absorbable and Biodegradable Polymers. Advances in Polymeric Biomaterials. CRC Press, South Carolina, pp. 77-85.

Sun, S., Mathias, J.D., Toussaint, E., Grédiac, M., 2013. Hygromechanical characterization of sunflower stems. Ind. Crops Prod. 46, 50-59.

Umemura, K., Mihara, A., Kawai, S., 2010. Development of new natural polymerbased wood adhesives III: effects of glucose addition on properties of chitosan. J. Wood Sci. 56, 387.

Zahedi, M., Tabarsa, T., Ashori, A., Madhoushi, M., Shakeri, A., 2013. A comparative study on some properties of wood plastic composites using canola stalk, paulownia and nanoclay. J. Appl. Polym. Sci. 129, 1491-1498. 